\title{
Assessment of Escherichia coli viability in coastal Sicilian waters by fluorescent antibody and $\beta$-glucuronidase activity methods
}

\author{
G. Caruso ${ }^{1}$, G. Zappalà ${ }^{1}$, R. Caruso ${ }^{2}$ \& E. Crisafi ${ }^{1}$ \\ ${ }^{1}$ Istituto per l'Ambiente Marino Costiero, \\ Consiglio Nazionale Ricerche, Messina, Italy \\ ${ }^{2}$ Azienda Ospedaliera Universitaria “G. Martino”, Messina, Italy
}

\begin{abstract}
Monitoring the viability of pathogens in bathing waters is crucial for public health preservation. The fluorescent antibody (FA)-viability method, using antibodies for Escherichia coli combined with CTC (5-cyano-2, 3 ditolyl tetrazolium chloride, marker of active respiring cells) or PI (propidium iodide, marker of membrane-damaged cells), and the $\beta$-glucuronidase activity test (by 4 methylumbelliferyl-b-d-glucuronide, MUG) offer interesting perspectives for detecting this bacterial indicator of faecal pollution. The viability of $E$. coli cells in Sicilian seawaters was evaluated on a seasonal scale $(\mathrm{n}=89$ samples) by FA and MUG compared to the standard culture method (by m-FC agar). The total microscopic counts obtained exceeded the culturable counts $(\mathrm{m}-\mathrm{FC})$ by one order of magnitude; actively respiring (CTC+) cells accounted, on average, for $63 \%$ of the total $E$. coli population. $\beta$-glucuronidase activity rates ranged from 0.00004 to $726.88 \mathrm{nmol}$ MUF $100 \mathrm{ml}^{-1} \mathrm{~h}^{-1}$, and were particularly enhanced during autumn and spring. The percentage of membrane-damaged cells increased in summer and in winter, probably due to adverse environmental conditions. In winter, high numbers of culturable cells suggested continental run-off to be an important source of pathogens; bacterial cells, however, were not actively respiring, but were membrane-damaged or with low metabolism, as indicated by the increase in PI counts and the decrease in MUG rates, respectively. In spring, increased numbers of CTC $(+)$ cells and $\beta$-glucuronidase rates suggested the recovery of some metabolic functions. Both methods used provided evidence that some viability properties were retained by $E$. coli cells after their discharge into seawater; therefore their combination could be proposed as a useful and rapid tool for environmental monitoring.

Keywords: Escherichia coli, marine waters, FA-viability, MUG.
\end{abstract}




\section{Introduction}

Bacterial pathogens introduced into coastal waters usually come from point sources such as rivers or urban effluents due to insufficient domestic wastewater treatment [1]. The hydrographical characteristics of the coastal systems which receive these inputs play an important role in controlling the distribution of pathogens. Due to their shallow water column, coastal zones may act as temporary "reservoirs" of pathogens, which can attach to sediment particles, getting further mobilized through sediment re-suspension [2]. Monitoring the viability of bacterial pathogens in recreational waters plays a crucial role for public health preservation.

Guidelines proposed for the control of pathogens in aquatic environments include the development and/or implementation of early warning systems to detect possible events (rainfall, continental discharges, sewage treatment plant failures) that may result in a deterioration of water quality levels. Since the last decade, our Institute undertook research lines addressed to advanced methods for coastal pollution monitoring, developing new rapid analytical protocols for early detection of pathogens in the environment. Among the analytical methods currently in use to quickly detect and enumerate Escherichia coli in seawater, as indicator of faecal pollution, the fluorescent antibody (FA)-viability, which combines the use of specific antibodies for enteropathogenic serotypes with the bacterial viability markers CTC (5-cyano-2, 3 ditolyl tetrazolium chloride, marker of active respiring cells) and PI (propidium iodide, marker of membranedamaged cells), and the $\beta$-glucuronidase activity (by 4-methylumbelliferyl- $\beta$-dglucuronide, MUG) assay offer interesting perspectives for monitoring seawater pollution $[1,3,4]$.

A seasonal study was performed to evaluate the efficacy of both these methods for estimating the viability of $E$. coli in seawaters in comparison with the standard culture method.

\section{Materials and methods}

\subsection{Samplings}

Since October 2002, a seasonal series of samplings of surface waters were performed along the coastal shoreline of Messina town, affected by urban discharges. Samples were collected from 8 sites, showing a wide range of pollution levels, in order to draw a complete description of hygienic-sanitary conditions of coastal waters. A total of 89 samples were collected using sterile bottles, divided in sub-volumes, and treated within two hours of sampling, according to the protocols further described.

\subsection{CTC-FA staining procedure}

The abundance of actively respiring cells was determined after simultaneous labelling with CTC and FA staining. The detailed procedure is reported by [3]. Briefly, $100 \mathrm{ml}$ of sample was incubated for $90 \mathrm{~min}$ in the dark at room 
temperature with CTC (Polysciences, Warrington, PA; final concentration, 5 mmol $\mathrm{l}^{-1}$ ) and then filtered through a $0.22 \mu \mathrm{m}$ polycarbonate black membrane (Whatman-Nuclepore, Maidstone, UK). The filter was incubated for 30 minutes with E. coli agglutinating sera, mix of pools $2+3+4$, specific for the enteropathogenic serotypes (Murex Biotech Limited, Abbott Park, Illinois, USA) (used at a 1:80 dilution in phosphate buffered saline, PBS, Sigma-Aldrich, St. Louis, USA). After rinsing with PBS, the filter was incubated for 30 minutes with a 1:160 dilution in PBS of goat anti rabbit IgG conjugated with fluorescein isothiocianate (FITC, Sigma-Aldrich), rinsed with PBS and mounted on a microscopic slide.

\subsection{FA-Live/Dead (L/D) staining procedure}

To determine the viability of $E$. coli cells, and therefore the concentration of membrane damaged cells, the combined FA-L/D staining procedure reported by [4] was followed. Water volumes of $100 \mathrm{ml}$ or less, depending on the turbidity of the sample, were filtered through a $0.22 \mu \mathrm{m}$ polycarbonate black membrane (Nuclepore) and further incubated for 15 minutes in the dark with propidium iodide (PI) stain, as a component of the Live/Dead (L/D) BacLight bacterial viability kit (Molecular Probes, Eugene, Oregon, USA). In order to verify that dead cells were efficiently stained by our FA-L/D protocol, prior to its application to the natural samples, a suspension of $E$. coli, killed by boiling, was used as a negative control.

\subsection{Microscopic observation}

Slides were observed with an epifluorescence microscope (Axioplan 2, Carl Zeiss S.p.A., Arese, Milano, Italia), equipped with an image analysis system. A total of 30 microscopic fields, chosen "at random", were viewed separately with fluorescein (blue light, BP 450-490, FT 510, LP 520) and rhodamine (green light, BP 510-560, FT 580, LP 590) filter sets. Through the FA-L/D staining procedure, it was possible to identify within the total (living + non-living) FAlabelled E. coli population, appearing as fluorescent green rods under blue light excitation, the fraction of cells that were dead or membrane-damaged (scored as PI-positive [PI+] cells) and therefore fluoresced red under green light, due to PI labelling (emission peak: 617-623 nm). The fraction of living cells was determined as the difference between the total FA-labelled E. coli cells and PI+ cells.

Using the CTC-FA procedure, the viable, actively respiring cells showed, under green light excitation, bright red fluorescence due to CTC-formazan crystals and were scored as CTC-positive $[\mathrm{CTC}+]$ cells. Cell counts were reported as the mean value of $E$. coli cells per $100 \mathrm{ml}$ of sample.

\section{$2.5 \beta$-glucuronidase activity}

For the assessment of this enzyme activity, increasing amounts ( 5 to $50 \mu \mathrm{mol} \mathrm{l}^{-1}$ ) of the fluorogenic substrate 4-methylumbelliferyl- $\beta$-D-glucuronide (MUG, Sigma, $0.5 \mathrm{mmol} \mathrm{l}^{-1}$ stock solution) were added to $10 \mathrm{ml}$ aliquots of a 10 times 
concentrated sample, according to the protocol of MUG assay [1]. The fluorescence released from the substrate was measured at time 0 , immediately after its addition, and after $3.5 \mathrm{~h}$ of incubation at $44^{\circ} \mathrm{C}$ with a spectrofluorometer (Cary Eclipse Fluorescence spectrophotometer, Varian Inc., Palo Alto, CA, USA) at 365 and $455 \mathrm{~nm}$ (excitation and emission wavelengths respectively). Calibration was performed with known concentrations (200, 400, $800 \mathrm{nmol} \mathrm{l}^{-1}$ ) of the standard MUF (Sigma, $0.5 \mathrm{mmol} \mathrm{l}^{-1}$ ). Potential enzyme activity rates were reported as maximum velocity of hydrolysis (Vmax, in nmol of MUF released $\left.100 \mathrm{ml}^{-1} \mathrm{~h}^{-1}\right)$.

\subsection{Culture counts}

The density of culturable cells (faecal coliforms, FC) was estimated after filtration of 10 and $100 \mathrm{ml}$ of sample through a $0.45 \mu \mathrm{m}$ porosity membrane (Millipore S.p.A., Vimodrone, MI, Italia), further incubated on $\mathrm{m}-\mathrm{FC}$ agar plates (Difco Inc., Detroit, MI, USA) at $44.5^{\circ} \mathrm{C}$ for $24 \mathrm{hrs}$ (according to [5]). Counts were expressed as the number of colony forming units (CFU) per $100 \mathrm{ml}$ of water. Cells were confirmed to belong to $E$. coli after addition of James indole reagent (Biomérieux, Marcy l'Etoile, France) to the colonies grown on $\mathrm{m}-\mathrm{FC}$ agar.

\subsection{Statistical analysis}

After logarithmic transformation of the data as a prerequisite to attain a normal distribution, Student' $t$ test was applied to test for statistical significance the differences among pairs of seasonal mean values obtained with each method used.

\section{Results}

The pattern of $E$. coli values obtained during our seasonal study is shown in Figure 1; in Table 1 the percentage contribution of each cell category to the total FA labelled population is reported. The concentration of total FA labelled E. coli cells did not display seasonal changes, ranging from $4.17 \times 10^{5}$ (summer) to 3.68 x $10^{5}$ cells $100 \mathrm{ml}^{-1}$ (winter) and decreasing in spring only, while plate counts underwent quantitative variations, being at their minimum in summer and increasing significantly in winter $(\mathrm{t}=3.023, \mathrm{P}<0.01$, winter $v s$ summer $)$. During summer, culturable $E$. coli accounted for a low percentage $(0.22 \%)$ of total FA counts, while their contribution to total $E$. coli population reached a maximum of $57.80 \%$ in winter. The high discrepancy between plate and microscopic counts observed in summer supported the hypothesis that a high percentage of target bacteria remained in seawater in a viable, but not culturable (VBNC) form.

On average, total-FA labelled $E$. coli counts exceeded by one order of magnitude the culturable (m-FC) counts. The concentration of living cells (not shown in Figure 1) was comprised between $1.95 \times 10^{5}$ (spring) and $3.77 \times 10^{5}$ cells $100 \mathrm{ml}^{-1}$ (autumn); these cells contributed to the total FA labelled E. coli population in a percentage ranging from 72.3 (in winter) to $96.21 \%$ (in autumn). 
Actively respiring $(\mathrm{CTC}+)$ cells were detected in concentrations ranging from $7.60 \times 10^{3}$ (winter) to $2.14 \times 10^{4}$ cells $100 \mathrm{ml}^{-1}$ (summer), when they represented, respectively, 20.67 and $51.30 \%$ of the total E. coli population. Dead or membrane damaged cells were found in concentrations comprised between $1.48 \times 10^{3}$ (autumn) and $7.79 \times 10^{3}$ cells $100 \mathrm{ml}^{-1}$ (summer), accounting for 3.79 and $18.69 \%$ of the total FA labelled E. coli, respectively.

The sum of the percentages of culturable, actively respiring and dead cells gave values lower than the total abundance $(100 \%)$ of $E$. coli, suggesting the existence of a fraction of bacterial cells that showed living attributes different from those detected in our study (i.e. other metabolic characteristics), therefore remaining still undetectable by our methods.

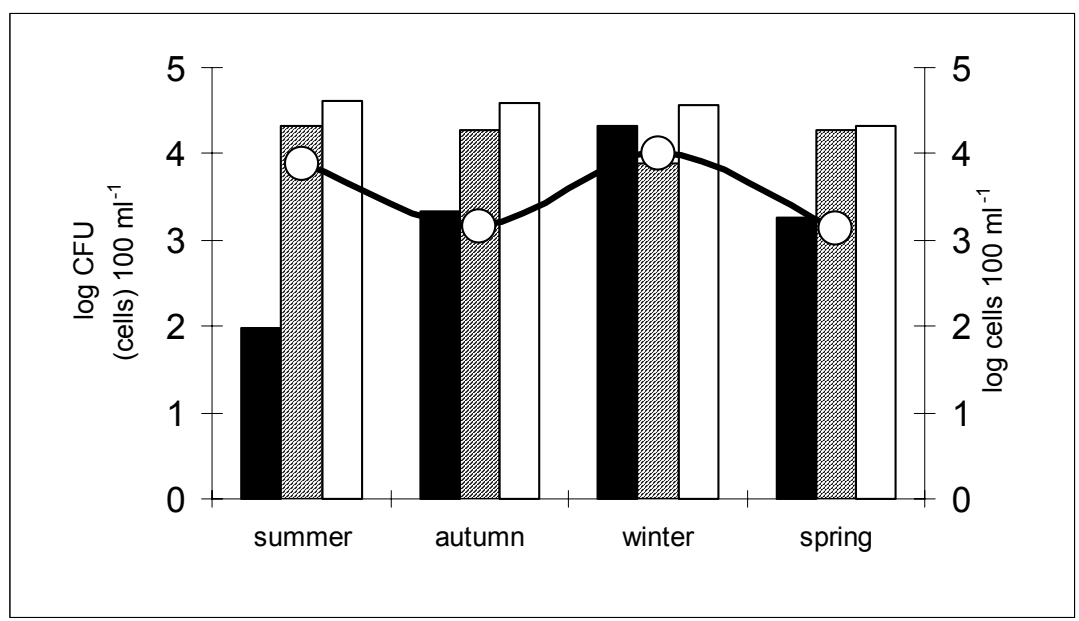

Figure 1: Seasonal distribution of E. coli concentrations recorded in Sicilian bathing waters, as obtained by different counting methods. Reported are: on the left axis, culturable counts on m-FC agar (black bars), total FA-labelled cell counts, calculated as the mean value obtained by both CTC-FA and FA-L/D staining procedures (white bars); actively respiring cells (CTC + cells, diagonally ruled bars); on the right axis, dead or membrane damaged $(\mathrm{PI}+$ ) cells (white circles).

Table 1: Contribution, reported as percentage, of the different E. coli physiological states to the total FA labeled E. coli population

\begin{tabular}{|l|c|c|c|}
\hline & $\begin{array}{c}\text { Culturable } \\
\text { cells }\end{array}$ & $\begin{array}{c}\text { Actively respiring } \\
(\mathrm{CTC}+) \text { cells }\end{array}$ & $\begin{array}{c}\text { Dead or membrane } \\
\text { damaged } \\
(\mathrm{PI}+) \text { cells }\end{array}$ \\
\hline summer & 0.22 & 63.10 & 18.69 \\
\hline autumn & 5.62 & 49.58 & 3.79 \\
\hline winter & 57.80 & 28.58 & 27.68 \\
\hline spring & 8.72 & 99.10 & 6.55 \\
\hline
\end{tabular}


Concerning the activity of $E$. coli cells, the estimates of the potential $\beta$ glucuronidase activity rates (Figure 2) provided values comprised between 0.0004 and $726.88 \mathrm{nM} \mathrm{MU} 100 \mathrm{ml}^{-1} \mathrm{~h}^{-1}$, revealing the presence of bacterial cells with an active lactose metabolism particularly during autumn and spring. The pattern followed by this parameter reflected the one displayed by cells retaining cell integrity.

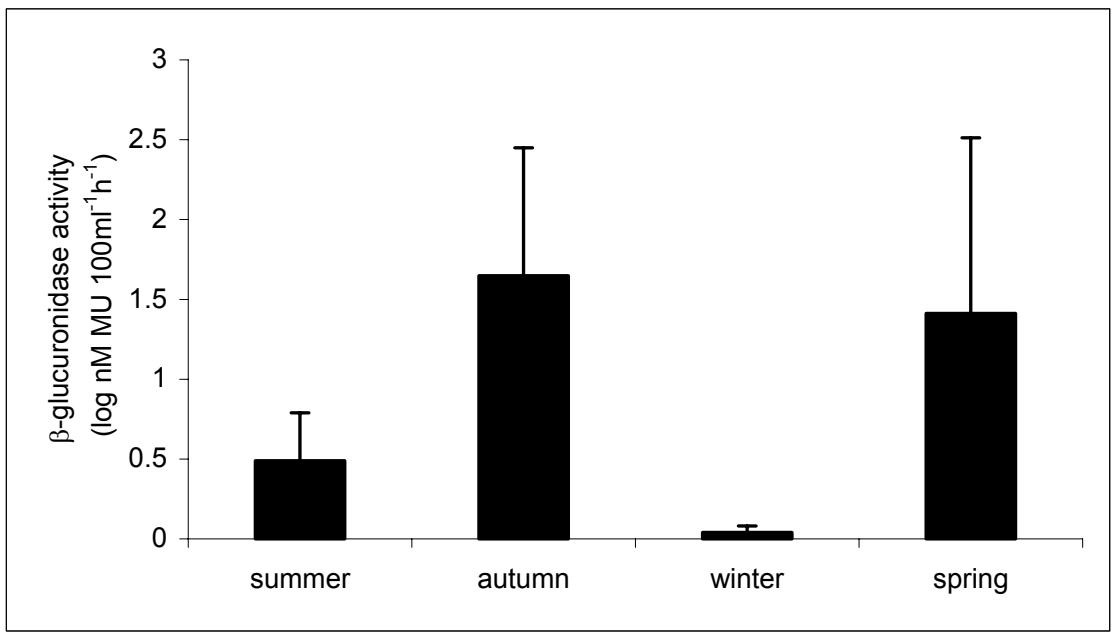

Figure 2: Seasonal values (mean \pm sd) of $\beta$-glucuronidase activity rates estimated by MUG assay.

In winter, culturable cells were found in high concentrations $\left(2.13 \times 10^{5}\right.$ cells $100 \mathrm{ml}^{-1}$ ); however, the increase in PI+ cells and the decrease in $\beta$ glucuronidase activity rates suggested that these cells were not actively respiring, but were membrane damaged or with low metabolism. In spring, an increase was noticed, both in the concentration of $\mathrm{CTC}+$ cells and in $\beta$-glucuronidase activity rates.

No significant seasonal differences were detected for any of the parameters measured, except for plate counts in winter (see before) and for $\beta$-glucuronidase activity rates, that increased significantly in autumn (Student's $\mathrm{t}=10.86, \mathrm{P}<$ 0.01 , autumn $v s$ summer) and in spring $(\mathrm{t}=7.709, \mathrm{P}<0.01$, spring $v s$ winter $)$.

The high CTC+ cell numbers and $\beta$-glucuronidase activity rates observed during autumn and spring were consistent with the degree of pollution recorded in the Sicilian coastal waters, reported in Figure 3. In fact, grouping data in frequency classes according to their pollution levels (namely by distinguishing them in low polluted samples, FC counts lower than $100 \mathrm{CFU} 100 \mathrm{ml}^{-1}$, and heavily polluted samples, FC counts higher than $100 \mathrm{CFU} 100 \mathrm{ml}^{-1}$ ), a low incidence of heavily polluted samples occurred during summer season. This indicated that the hygienic-sanitary conditions of coastal seawaters were good. Conversely, a deterioration in water quality levels was recorded in autumn and in 
spring. During these seasons the best correlations between m-FC, CTC and MUG and total FA were observed, leading us to conclude that the persistence of viable cells retaining active respiration and metabolism was associated with high pollution levels.

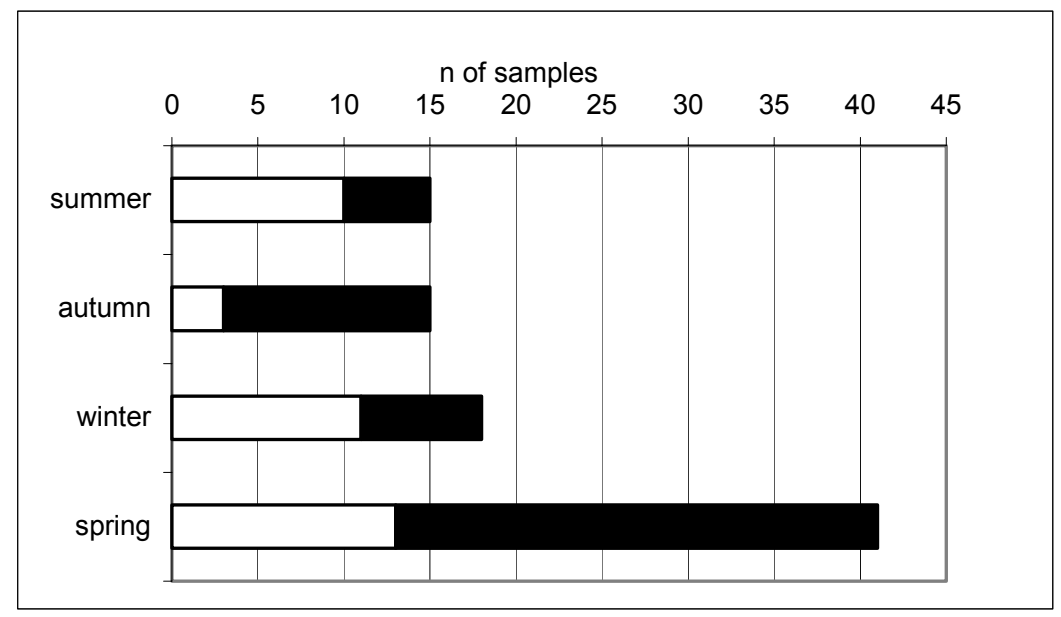

Figure 3: Microbiological quality levels of Sicilian bathing waters obtained during this study, by grouping samples $(n=89)$, according to their pollution level, in slightly polluted (showing FC concentrations lower than $10^{2} \mathrm{CFU} 100 \mathrm{ml}^{-1}$ ) and heavily polluted samples (whose FC counts exceeded $10^{2} \mathrm{CFU} 100 \mathrm{ml}^{-1}$ ).

The comparison, by linear regression, among all the bacterial counts and activity data obtained by the different methods used, showed that $\mathrm{FC}$ values were significantly related to the concentration of CTC + cells $(\mathrm{r}=0.483, \mathrm{P}<0.01)$, as well as to MUG activity rates $(\mathrm{r}=0.520, \mathrm{P}<0.01)$ (Figures 4 and 5). This finding suggested that the culturable fraction displayed also active respiration and lactose metabolism.

\section{Discussion}

During our study, the viability of $E$. coli cells after seawater discharging was evaluated comparing together bacterial abundance and activity data. Furthermore, in order to obtain a complete picture of the different degrees of viability of bacterial cells in seawater, we evaluated different features of bacterial metabolism, using viability stains or assays as multiple parameters indicating cell viability. In fact, they concerned active respiration (such as CTC, a compound involved in electron transport chain and therefore giving information on the efficacy of the respiratory metabolism) or lactose metabolism (such as $\beta$ glucuronidase activity assay) or structure integrity (such as PI, stain able to 
penetrate through damaged membranes only). The comparison of both abundance and activity data obtained proved $E$. coli cells underwent seasonal changes, being able to survive in seawater under different physiological states.

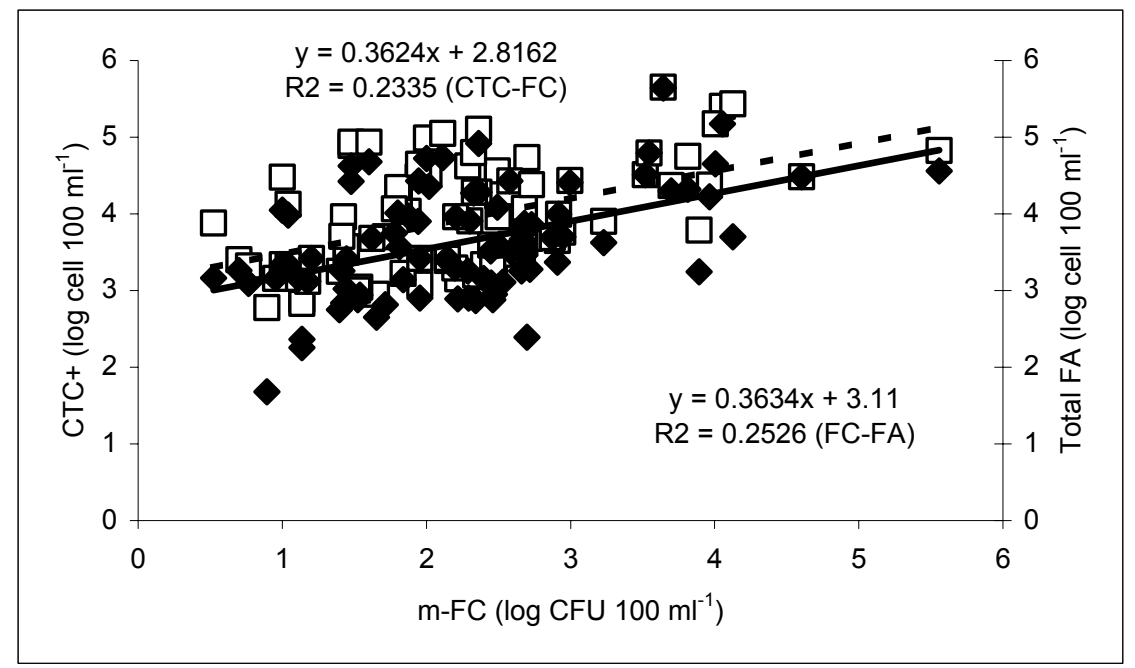

Figure 4: Linear regression of culture counts (m-FC) versus actively respiring cells (CTC+, black rhombus, continuous line) and total FA labelled cells (dotted line, white squares) ( $\mathrm{n}=89$ samples).

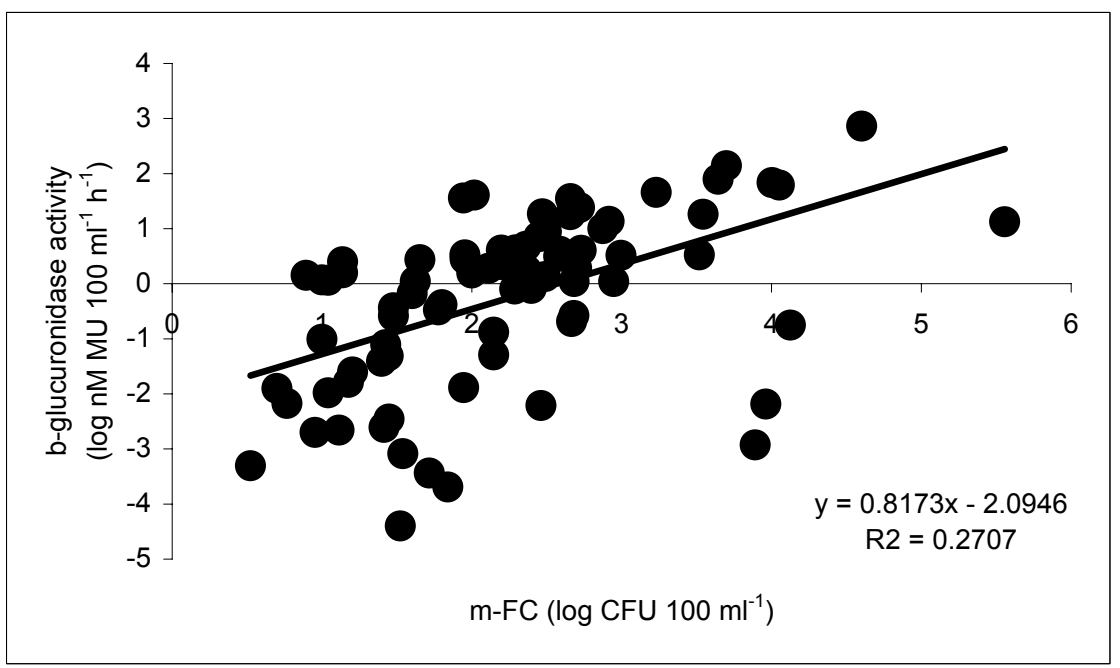

Figure 5: Linear regression of culture counts $(\mathrm{m}-\mathrm{FC})$ versus $\beta$-glucuronidase (MUG) activity rates $(\mathrm{n}=89$ samples). 
Within the total E. coli population, during summer, a low number of cells able to grow on media were detected, while dead cells were found in high concentrations, probably due to the negative affect of solar irradiance; cells were also actively respiring but displayed low lactose metabolism, suggesting the occurrence of a high percentage of VBNC or stressed cells. In autumn, the concentration of culturable cells increased, which retained an active respiration; cells recovered also their functionality in lactose metabolism and the number of living cells increased, while the one of membrane damaged cells decreased.

During winter, the importance of continental run-off as a source of pathogens or organic matter supporting bacterial survival was suggested by the peak concentration of culturable cells detected; these, however, were membrane damaged or entered a phase similar to quiescence or stationary phase, reducing significantly their lactose metabolism and active respiration. These metabolic changes allowed them to overcome adverse environmental conditions. In spring, the culturable cells were at their minimum value, but they consisted of cells with active lactose metabolism and respiration and with intact membranes. The recovery of metabolic functions was made possible due to environmental conditions becoming favourable to bacteria. The presence of a wide range of metabolic states has been shown in natural microbial assemblages occurring in aquatic environments $[6,7]$; on the other hand, abiotic (solar radiation, nutrient availability, temperature, osmotic stress) and biotic (predation) factors are recognised as the most important factors controlling the survival of allochthonous bacteria, such as enteric pathogens, in marine waters [8].

In conclusion, all the methods applied during this investigation provided results well correlated with current standard counts, were sensitive and low in terms of time and cost. They proved to be suitable to follow the evolution of the viability of bacterial pathogens in seawater; consequently they may represent an attractive alternative approach for monitoring the microbiological quality of bathing waters. Our study suggested also the importance of combining different analytical methods for a better understanding of the distribution and persistence of $E$. coli in coastal waters; other than the microscopic methods [3, 4], also the estimation of the $\beta$-glucuronidase activity by MUG assay has been successfully applied for the screening of bathing waters, allowing the early warning of faecal contamination $[1,9]$.

This operational approach can provide a strategy of primary significance to adapt the development of better risk assessment programs to the effective amount of bacteria retaining potential pathogenicity.

\section{Acknowledgement}

Work funded by Cluster 10 MIUR “SAM” research program.

\section{References}

[1] Caruso, G., Crisafi, E., \& Mancuso, M., Development of an enzyme assay for rapid assessment of Escherichia coli in seawaters. Journal Applied Microbiology, 93(4), pp. 548-556, 2002. 
[2] Pommepuy, M., Hervio-Heath, D., Gourmelon, M., Caprais, M.P., Le Cann, P., Le Saux, J.C., \& Le Guyader, F., Emerging pathogens in coastal areas. Proc. of CIESM Workshop, Novel contaminants and pathogens in coastal waters, CIESM Workshop Monographs, CIESM: Monaco, 26, pp. 1-112, 2004.

[3] Caruso, G., Mancuso, M., \& Crisafi, E., Combined fluorescent antibody assay and viability staining for the assessment of the physiological states of Escherichia coli in seawaters. Journal Applied Microbiology, 95, pp. 225233, 2003.

[4] Caruso, G., De Pasquale, F., Mancuso, M., Zampino, D., \& Crisafi, E., Fluorescent antibody-viability staining and enzyme methods as rapid tools for monitoring Escherichia coli viability in coastal marine waters. Journal of Immunoassays and Immunochemistry, 27, pp. 1-13, 2006.

[5] American Public Health Association (A.P.H.A.), Standard methods for the examination of water and waste water, 18th Ed. American Public Health Association: Washington, DC, 1992.

[6] Smith, E.M. \& del Giorgio, P.A., Low fractions of active bacteria in natural aquatic communities? Aquatic Microbial Ecology, 31, pp. 203-208, 2003.

[7] Petit, M., George, I., \& Servais, P., Survival of Escherichia coli in freshwater: beta-D-glucuronidase activity measurements and characterization of cellular states. Canadian Journal of Microbiology, 46, pp. 679-684, 2000.

[8] Rozen, Y. \& Belkin, S., Survival of enteric bacteria in seawater. FEMS Microbiology Reviews, 725, pp. 1-17, 2001.

[9] Lebaron, P., Henry, A., Lepeuple, A.-S., Pena, G. \& Servais, P., An operational method for the real-time monitoring of $E$. coli numbers in bathing waters. Marine Pollution Bulletin, 50, pp. 652-659, 2005. 